Nig. J. Pure \& Appl. Sci. Vol. 33 (Issue 1, 2020)
e-ISSN 2756-4045
Life Sciences, Univ. of Ilorin, Nigeria
www.njpas.com.ng

doi: http://dx.doi.org/10.48198/NJPAS/20.A16

\title{
Multi-Drug Resistant Salmonella typhi among Out-Patients in Hospitals within Ilorin, Nigeria and their Susceptibility to Cymbopogon Citratus
}

\author{
Ibikunle Ibitayo Anibijuwon ${ }^{1 *}$, Adetutu Adedokun ${ }^{1}$, Suleiman Muhammed Mustapha², Olafimihan \\ Christiana Abiola ${ }^{3}$ and Olanrewaju Sariyat Olayinka ${ }^{4}$.
}
${ }^{1}$ Department of Microbiology, Public Health Laboratory Unit, Faculty of Life sciences, University of Ilorin, Ilorin.
${ }^{2}$ Institute of Molecular Science and Biotechnology, University of Ilorin, Ilorin, Kwara State.
${ }^{3}$ Department of Science Technology, Federal Polytechnic Offa, Nigeria Department of Applied Sciences, Osun State Polytechnic, Iree

\begin{abstract}
The indiscriminate use of drugs, medication and non-adherence are one of the factors that has led to the emergence of multi-drug resistant Salmonella typhi. This study was conducted to assess the incidence of typhoid fever among out-patients in some selected Specialist Hospitals in Ilorin Metropolis and to determine the susceptibility of the causative agent to antibiotics and plant extract of Cymbopogon citratus. A cross-sectional survey was completed over a five-month surveillance period in these four locations namely: The Children Specialist Hospital Centre Igboro; Cottage Hospital; Adewole Specialist Hospital Alagbado; and Civil Service Hospital with a total of about 400 blood samples from out-patients across ages. Antibiogram profiling of the isolates to standard gram-negative antibiotics and antibacterial activity of Cymbopogon citratus extracts were determined using disc diffusion method. A total of Eight (8) Salmonella typhi isolates were recovered collectively from the patients. All the isolates were multi-drug resistant with a notable resistance to chloramphenicol, ampicillin and co-trimoxazole. Molecular confirmation of the isolates showed DNA size of 500 base pairs. The ethanolic extract of Cymbopogon citratus was more potent with MIC of $12.5 \mathrm{mg} / \mathrm{ml}$ and MBC $25 \mathrm{mg} / \mathrm{ml}$ while the phytochemical screening of the plants revealed the presence of alkaloids, flavonoids, phenols, tannins, saponins, steroids and glycosides. The promising outcome of the plant extract against Salmonella typhi posits its possible application in treatment against the infectious agent.
\end{abstract}

Keywords: Antibiotics, Antibacterial, Typhoid Fever, Resistance, Infection.

\section{Introduction}

Salmonella typhi, a motile, facultative anaerobe, is a typical Salmonella serovar that causes typhoid fever which pose a major threat to general health in developing countries (Qamar et al., 2014). Typhoid fever is a systemic infection which may last for about three to four weeks and death rate ranges between $12 \%$ and $30 \%$. There has been a decrease in the worldwide spread of typhoid fever; however, the emergence of multi-drug resistant $S$. typhi (MDRST) is still a threat to public health. There exist about 107 strains of this organism with varying metabolic characteristics, virulence level,

\section{Corresponding Author: Ibikunle Ibitayo Anibijuwon}

Department of Microbiology, Public Health Laboratory Unit, Faculty of Life sciences, University of Ilorin, P.M.B. 1515, Ilorin, Nigeria. Phone: +2348036115296: Email: kunledoexploit@unilorin.edu.ng, 
and multi-drug resistant genes that complicates treatment in prevalent areas (Parkhill et al.,2001; Deng et al., 2003).

Despite the emergence of newer antibacterial drugs, enteric fever has continued to be a major

Page | 3629 health problem (Zaki and Karande, 2011). Resistance of $S$. typhi to antibiotics like ampicillin, ceftriaxone, co-trimoxazole, and ciprofloxacin (Sehra et al., 2013) further depicts the complications that could arise from the disease condition and thus poses greater challenge in its management.

\section{Cymbopogon citratus (Lemongrass)}

Cymbopogon citratus of the Poaceae family is a tall, monocotyledonous aromatic perennial plant with slender sharp-edge green leaves and pointed apex. Lemongrass, Cymbopogon citratus is one of the important leaves among the species of grasses, and has various applications in traditional medicine (Ernst, 2008). In Nigeria, the Edos call it: eti, Efik: Ikon eti, Hausa call it: tsauri, Ibibio: myobaka makara, Igbo (Owerri) call it: achara ehi and Yoruba call it: kooko oba (Ahmad and Beg, 2001). Lemongrass ranked highest in inhibitory activity against methicillin-resistant Staphylococcus aureus (MRSA) infection, helpful in relieving colitis indigestion/gastro-enteritis ailments and relieves the symptoms of headache, body ache, nervous exhaustion and stress-related conditions amongst others (Joseph, 2005). The aim of the research is to molecularly detect the occurrence of multidrug resistant (MDR) Salmonella typhi among out-patients attending Major Health Institutions in Ilorin metropolis, Nigeria. The efficacy of commercially available antibiotics and different extracts of Cymbopogon citratus on the detected isolates was also evaluated.

\section{Materials and Methods \\ Study Area and Population}

This study was carried out in four selected tertiary hospitals within Ilorin, Kwara state, Nigeria, including: Children Specialist Hospital Centre Igboro (CSH); Cottage Hospital, Adewole (CHA);
Specialist Hospital Alagbado (SHA); and Civil Service Hospital, G.R.A (CSHG). These hospitals have facilities to attend to chronic health issues and they are accessible to patients seeking medical consultation. Consenting age groups (children, adults and aged) who were out-patients in the selected hospitals were sampled. A structured close-ended questionnaire was shared among consenting subjects to gather information about the socio-demographic characteristics such as age, gender, socioeconomic status such as level of education, occupation, the use of antibiotics and patients' exposures to the risk factors associated with typhoid fever. The survey/ sample collection was carried out in all the four locations from September, 2017 to June, 2018. A total of four hundred (400) subjects were recruited for this study. One hundred (100) blood samples was obtained from consenting subjects in each of the four (4) different hospitals.

\section{Sample Collection}

About $5 \mathrm{ml}$ of blood samples were aseptically obtained from subjects using a sterile needle and syringe, dispensed directly into sterile blood culture bottles containing thioglycolate broth, placed in ice packs and transported to the laboratory for analysis. Samples were labeled according to the serial number allotted to the questionnaire filled by the patients.

\section{Identification and Phytochemical Screening of Plant Extracts}

The leaf of Cymbopogon citratus (Lemon grass) was sourced from farms by herbal practitioners in Ilorin town, Nigeria. Identification and authentication of the plant was done at the Department of Plant Biology Herbarium, University of Ilorin, Ilorin, Nigeria, with voucher number UILH/001/1284. Phytochemical analysis was performed to screen the extracts for the presence of alkaloids, flavonoids, phenols, tannins, steroids, saponins and glycosides. All procedures 
were as described by Geetha and Geetha, (2014) with slight modifications.

\section{Bacteriological Analysis}

Isolation and identification of Salmonella typhi Page | 3630 from the samples was done by culturing on Salmonella-Shigella agar and incubated at $37^{\circ} \mathrm{C}$ for 24 hours. Biochemical test was carried out using Hi2 $5^{\mathrm{TM}}$ Enterobacteriaceae identification kit (HiMedia laboratories, India). The in vitro sensitivity testing of the $S$. typh $i$ isolates to different

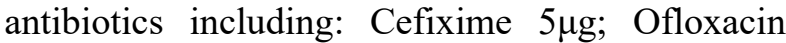
$5 \mu \mathrm{g} ; \quad$ Ciprofloxacin $5 \mu \mathrm{g} ; \quad$ Ampicillin $5 \mu \mathrm{g}$;

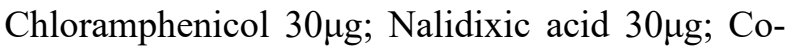
trimoxazole $25 \mu \mathrm{g}$; and Nitrofurantoin $30 \mu \mathrm{g}$ (Rapid labs, UK and Oxoid, UK) were carried out as recommended by the Clinical and Laboratory Standards Institute using the Kirby-Bauer agar disc diffusion method(Bauer et al., 1966). The ethanolic and methanolic extracts were prepared according to the methods of Arya et al. (2014) and Al- Mansoub et al. (2013), to get the crude extract. The antibacterial activity of these extracts against these isolates was done using agar well diffusion method (Bauer et al., 1966). The Minimum inhibitory and bactericidal concentrations of the extracts were determined using dilution susceptibility test against the seeded standardized isolates on Mueller Hinton broth.

\section{Molecular Identification of Isolates}

The Zymo Bacterial/Fungal DNA mini prep ${ }^{\mathrm{TM}}$ kit (Vesty et al., 2017) was used for DNA extraction following the manufacturer's specifications and guidelines. Extracted DNA were subjected to polymerase chain reactions (PCR) using the primer of Haim et al., 2008. Briefly, the PCR master mix was prepared containing $0.8 \mu \mathrm{l}$ deoxynucleoside triphosphate (dNTPs), $2.5 \mu 1$ PCR buffer, $0.2 \mu 1$ thermos aquaticus (Taq) polymerase, $1.5 \mu 1 \mathrm{MgCl}_{2}$, $5 \mu 1$ DNA lysates, $11 \mu 1$ of PCR water and $2 \mu 1$ of primers. Twenty-five $(25 \mu l)$ total volume reaction was used containing $20 \mu \mathrm{l}$ of aliquot of master mix with $5 \mu 1$ of DNA lysate were put in eppendorf tubes. Controls were set along with the samples and put in the PCR machine. Reactions consisted of an initial denaturation phase $\left(95^{\circ} \mathrm{C}\right.$ for $\left.5 \mathrm{~min}\right)$, followed by 30 cycles of denaturation, annealing and elongation. The denaturation phase was performed at $95^{\circ} \mathrm{C}$ for 30 seconds. The annealing temperatures were varied according to the primers used and were also for 30 seconds. The elongation phase was also performed for 30 seconds at $72^{\circ} \mathrm{C}$ and a final elongation step of $10 \mathrm{~min}$ at $72^{\circ} \mathrm{C}$. The PCR products with the DNA ladder were subjected to agarose gel electrophoresis at $100 \mathrm{~V}$ for 25 minutes, after which the bands were visualized under ultra violet (UV) light on a Gene Genius' image analyzer (SYNGENE, Cambridge, UK).

\section{Ethical Approval}

Ethical approval was obtained from the University Ethical Review Committee, University of Ilorin, Ilorin, Nigeria (UERC/ASN/2018/1113) and Ministry of Health, Ilorin, Nigeria. Patients consent were sought and questionnaire administered before the collection of samples.

\section{Results}

The percentage age distribution of the subjects used in this study at each location is shown in Figure 1. Amongst all the subjects, only CHA had 4\% occurrence of aged 70years and above while $\mathrm{CSH}$ had $2 \%$ of aged $61-70$. Others had varying percentage distribution across the age groups between $0-60$ years. The percentage characteristics of the subjects as regard to gender, education, religion, marital status and profession is shown in Table 1. The evaluation of the medical history and predisposing factors associated with typhoid fever is shown in Table 2. In all four locations, the records of previous diagnosis of typhoid fever was over $45 \%$. Poor personal hygiene and sanitation habit was zero (0) in all locations except SHA with $13 \%$.

A total of Eight (8) blood samples were positive for S. typhi in all the sample location, except CSHG as 
shown in Table 3. Isolates B7, B23, B47 and B57 were recovered from $\mathrm{CSH}$; $\mathrm{B} 28$, B51, B76 from $\mathrm{CHA}$; and B58 from SHA. Higher occurrence was observed in males compared to females.

\section{Page | 3631 Sensitivity pattern of isolates to commercial antibiotics}

The isolates displayed varying sensitivities to the test antibiotics as shown in Table 4. All the isolates were resistant to Ampicillin, chloramphenicol, Nalidixic acid and cotrimoxazole. S. typhi B47 showed the highest multi resistant pattern to all the test antibiotics, while $S$. typhi B7 and B51 were the most sensitive.

\section{Antibacterial activity of Cymbopogon citratus against the test isolates}

The ethanolic and methanolic extracts of Cymbopogon citratus were effective on the isolates; however, the ethanolic extract had better antibacterial activity with zone of inhibition ranging from $11.5 \mathrm{~mm}-16.9 \mathrm{~mm}$ as shown in Figure 2. The MIC carried out on the isolates that were sensitive to the extracts recorded a concentration of at least $6.25 \mathrm{mg} / \mathrm{ml}$ while the least $\mathrm{MBC}$ concentration was recorded at $12.5 \mathrm{mg} / \mathrm{ml}$ as shown in Table 5.

The phytochemicals present in the extracts of Cymbopogon citratus are shown in Table 6. Only alkaloids and saponins were absent in methanol extract compared to ethanol extract.

The molecular identification of $S$. typhi isolates revealed clear bands around 500bp in lane 1 and 2 as shown in Figure 3.

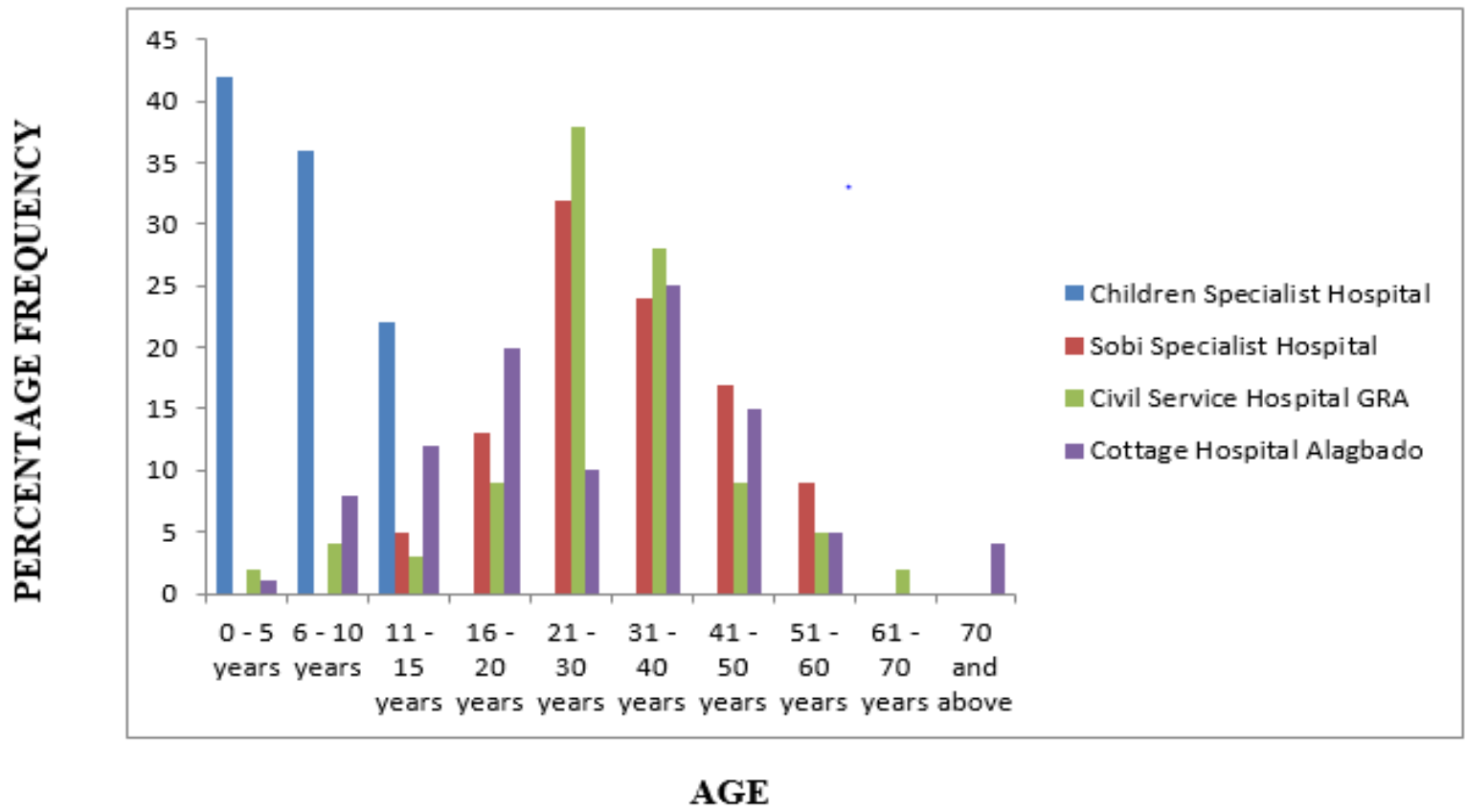

Figure 1: Age distribution amongst the respondents. 
Table 1: Demographic characteristics of the subjects used in the study

\begin{tabular}{|c|c|c|c|c|c|}
\hline & \multirow[t]{2}{*}{ FEATURES } & \multicolumn{4}{|c|}{ Percentage Frequency of respondents } \\
\hline & & CSH & SHA & CSHG & CHA \\
\hline \multirow{26}{*}{ Page | 3632} & SEX & & & & \\
\hline & Female & 58 & 63 & 68 & 60 \\
\hline & Male & 42 & 37 & 32 & 40 \\
\hline & TYPE OF DUCATION & & & & \\
\hline & Informal & 52 & 73 & 46 & 63 \\
\hline & Formal & 48 & 27 & 54 & 37 \\
\hline & $\begin{array}{l}\text { HIGHEST LEVEL OF } \\
\text { EDUCATION }\end{array}$ & & & & \\
\hline & Primary & 15 & 18 & 10 & 7 \\
\hline & Post Primary & 12 & 4 & 7 & 15 \\
\hline & Secondary & 11 & 2 & 10 & 5 \\
\hline & Tertiary & 10 & 3 & 27 & 10 \\
\hline & RELIGION & & & & \\
\hline & Christianity & 33 & 30 & 46 & 43 \\
\hline & Islam & 67 & 70 & 54 & 57 \\
\hline & Others & 0 & 0 & 0 & 0 \\
\hline & MARITAL STATUS & & & & \\
\hline & Single & 15 & 33 & 27 & 38 \\
\hline & Married & 82 & 64 & 71 & 60 \\
\hline & Widowed & 2 & 3 & 1 & 2 \\
\hline & Divorced & 1 & 0 & 1 & 0 \\
\hline & PROFESSION & & & & \\
\hline & Top Civil servant executive & 8 & 5 & 26 & 10 \\
\hline & $\begin{array}{l}\text { Middle class/small scale } \\
\text { business }\end{array}$ & 20 & 22 & 40 & 29 \\
\hline & Low class & 40 & 31 & 11 & 26 \\
\hline & Artisan & 12 & 26 & 19 & 22 \\
\hline & Others & 20 & 16 & 4 & 13 \\
\hline
\end{tabular}

Values represent the frequency and corresponding percentage $(n=100)$

CSH $=$ Children Specialist Hospital; SHA = Specialist Hospital Adewole; CSHG $=$ Civil Service Hospital,

G.R.A CHA= Cottage Hospital, Adewole 
Table 2: Medical history and predisposing factors estimated among subjects

\begin{tabular}{lcccc}
\hline \multirow{2}{*}{ FEATURES } & \multicolumn{4}{c}{ Percentage frequency of respondents (\%) } \\
\cline { 2 - 5 } & CSH & SHA & CSHG & CHA \\
\hline PREVIOUS DLAGNOSIS & & & & \\
OF TYPHOID & 46 & 63 & 43 & 60 \\
\hline Yes & 54 & 37 & 40 \\
No & & & 49 & 43 \\
\hline MODE OF TREATNENT & 41 & 42 & 31 & 37 \\
\hline Self-medication & 21 & 35 & 20 & 20 \\
Pharmacy & 38 & 23 & & \\
Hospital & & & 40 & 25 \\
\hline MEDICATION & & 29 & 60 & 75 \\
ADHERENCE & 57 & 71 & & 4 \\
\hline Yes & 43 & & & \\
No & & & & \\
\hline
\end{tabular}

PERSONAL HYGIENE

AND SANITATION

\begin{tabular}{lcccc}
\hline Poor & 0 & 13 & 0 & 0 \\
Fair & 31 & 49 & 10 & 25 \\
Good & 59 & 25 & 31 & 56 \\
Excellent & 10 & 13 & 59 & 19 \\
\hline WATER SOURCE & & 57 & 79 & 22 \\
\hline Tap/ Borehole & 26 & 5 & 21 & 76 \\
Well & 74 & 8 & 0 & 2 \\
Stream & 0 & & & \\
\hline
\end{tabular}

Values represent the frequency and corresponding percentage $(n=100)$

CSH= Children Specialist Hospital; SHA= Specialist Hospital Adewole; CSHG= Civil Service Hospital, G.R.A CHA= Cottage Hospital, Adewole

Table 3: Distribution of $S$. typhi recovered from blood samples of subjects

\begin{tabular}{ccccc}
\hline $\begin{array}{c}\text { STUDY } \\
\text { LOCATION }\end{array}$ & AGE & MALE & FEMLALE & TOTAL \\
\hline CSH & $0-5$ & 0 & 1 & 1 \\
& $6-10$ & 3 & 0 & 3 \\
\hline SHA & $51-60$ & 0 & 1 & $\mathbf{1}$ \\
\hline CHA & $16-20$ & 3 & 0 & 3 \\
\hline & TOTAL & $\mathbf{6}$ & $\mathbf{2}$ & $\mathbf{3}$
\end{tabular}


Table 4: Susceptibility pattern of $S$. typhi isolates to commercial antibiotics

\begin{tabular}{|c|c|c|c|c|c|c|c|c|}
\hline \multirow{2}{*}{ Isolates } & \multicolumn{8}{|c|}{ Antibiotics } \\
\hline & CXM & OFL & AMP & CPR & CPL & NAL & COT & NIT \\
\hline S. typhi B7 & $\mathrm{S}$ & $\mathrm{S}$ & $\mathrm{R}$ & $\mathrm{S}$ & $\mathrm{R}$ & $\mathrm{R}$ & $\mathrm{R}$ & $\mathrm{S}$ \\
\hline S. typhi $\mathrm{B} 23$ & $\mathrm{R}$ & $\mathrm{S}$ & $\mathrm{R}$ & $\mathrm{R}$ & $\mathrm{R}$ & $\mathrm{R}$ & $\mathrm{R}$ & $\mathrm{S}$ \\
\hline S. typhi B28 & $\mathrm{S}$ & $\mathrm{S}$ & $\mathrm{R}$ & $\mathrm{S}$ & $\mathrm{R}$ & $\mathrm{R}$ & $\mathrm{R}$ & $\mathrm{R}$ \\
\hline S. typhi B47 & $\mathrm{S}$ & $\mathrm{R}$ & $\mathrm{R}$ & $\mathrm{R}$ & $\mathrm{R}$ & $\mathrm{R}$ & $\mathrm{R}$ & $\mathrm{R}$ \\
\hline S. typhi B51 & $\mathrm{S}$ & $\mathrm{S}$ & $\mathrm{R}$ & $\mathrm{S}$ & $\mathrm{R}$ & $\mathrm{R}$ & $\mathrm{R}$ & $\mathrm{S}$ \\
\hline S. typhi B57 & $\mathrm{S}$ & $\mathrm{R}$ & $\mathrm{R}$ & $\mathrm{S}$ & $\mathrm{R}$ & $\mathrm{R}$ & $\mathrm{R}$ & $\mathrm{S}$ \\
\hline S. typhi B58 & $\mathrm{S}$ & $\mathrm{S}$ & $\mathrm{R}$ & $\mathrm{S}$ & $\mathrm{R}$ & $\mathrm{R}$ & $\mathrm{R}$ & $\mathrm{R}$ \\
\hline S. typhi B76 & $\mathrm{S}$ & $\mathrm{S}$ & $\mathrm{R}$ & $\mathrm{S}$ & $\mathrm{R}$ & $\mathrm{R}$ & $\mathrm{R}$ & $\mathrm{R}$ \\
\hline
\end{tabular}

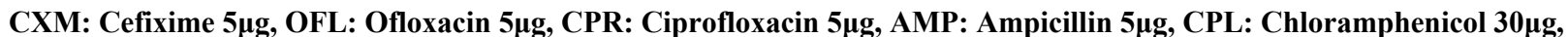

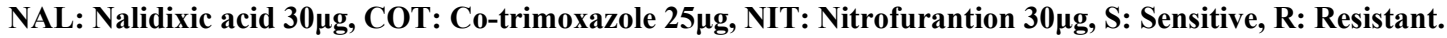

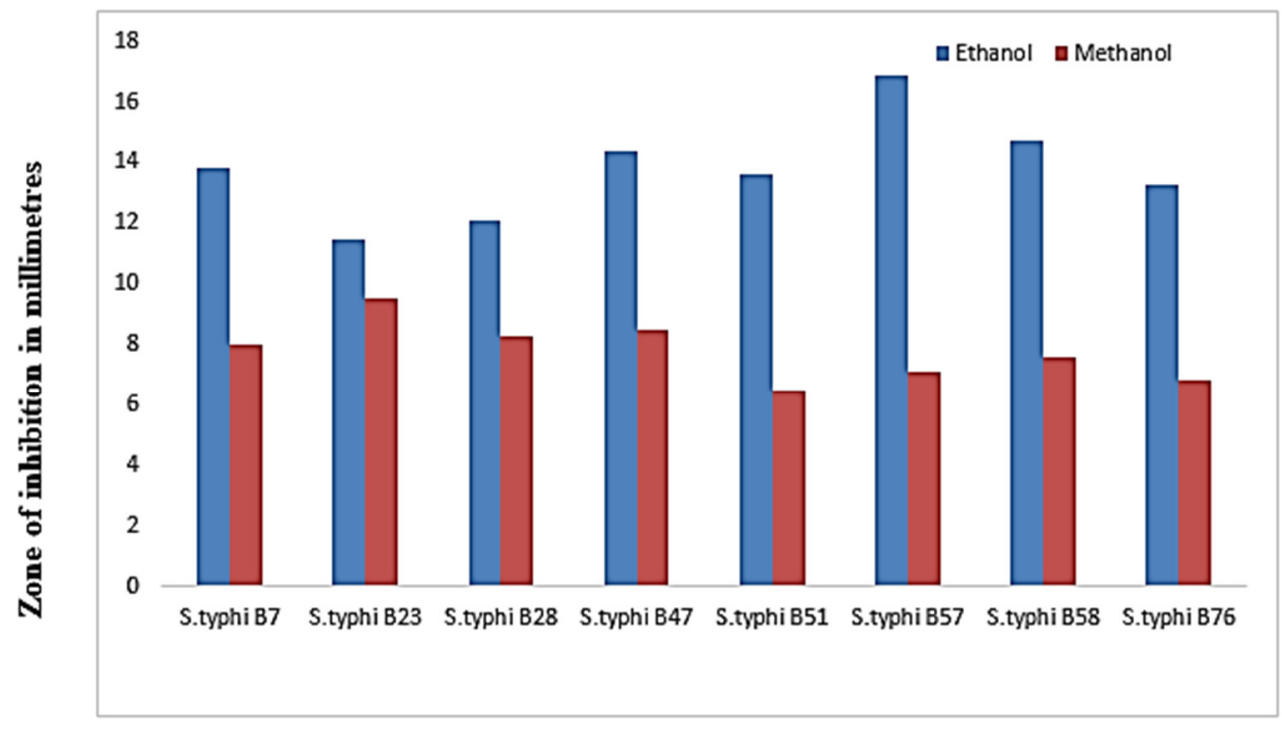

Isolates

Figure 2: Antimicrobial activity of ethanol and methanol extracts of Cymbopogon citratus against the $S$. typhi isolates. 
Table 5: Minimum Inhibitory Concentration (MIC) and Minimum Bactericidal Concentration (MBC) of ethanol and methanol extracts of Cymbopogon citratus against the S. typhi isolates.

\begin{tabular}{|c|c|c|c|c|c|c|c|c|c|c|c|c|c|c|}
\hline \multirow{3}{*}{ Isolates } & \multicolumn{12}{|c|}{ MIC (mg/ml) } & \multicolumn{2}{|c|}{ MBC (mg/ml) } \\
\hline & \multirow[b]{2}{*}{$\overline{3.125}$} & \multicolumn{5}{|c|}{ Ethanol } & \multicolumn{6}{|c|}{ Methanol } & \multirow[t]{2}{*}{ Ethanol } & \multirow[t]{2}{*}{ Methano } \\
\hline & & 6.25 & 12.5 & 25 & 50 & 100 & 3.125 & 6.25 & 12.5 & 25 & 50 & 100 & & \\
\hline S. typhi B7 & + & + & - & - & - & - & + & + & + & - & - & - & 25 & 50 \\
\hline S. typhi B23 & + & + & + & - & - & - & + & + & - & - & - & - & 50 & 25 \\
\hline S. typhi B28 & + & + & + & - & - & - & + & + & + & - & - & - & 50 & 50 \\
\hline S. typhi $B 47$ & + & + & - & - & - & - & + & + & + & - & - & - & 25 & 50 \\
\hline S. typhi B51 & + & + & - & - & - & - & + & + & - & - & - & - & 25 & 25 \\
\hline S. typhi B57 & + & - & - & - & - & - & - & + & - & - & - & - & 12.5 & 25 \\
\hline S. typhi B58 & + & + & - & - & - & - & + & + & + & - & - & - & 25 & 50 \\
\hline S. typhi B76 & + & + & - & - & - & - & + & + & + & - & - & - & 25 & 50 \\
\hline
\end{tabular}

$$
\text { Key: }+=\text { bacterial growth, }-=\text { no bacterial growth }
$$

Table 2: Phytochemical screening of Cymbopogon citratus extracts.

\begin{tabular}{ccc}
\hline & \multicolumn{3}{c}{ Extracts } \\
\hline Phytochemicals & Ethanol & Methanol \\
\hline Alkaloids & + & - \\
Flavonoids & + & + \\
Phenols & + & + \\
Tannins & + & + \\
Saponins & + & - \\
Steroids & + & + \\
Glycosides & + & + \\
\hline
\end{tabular}

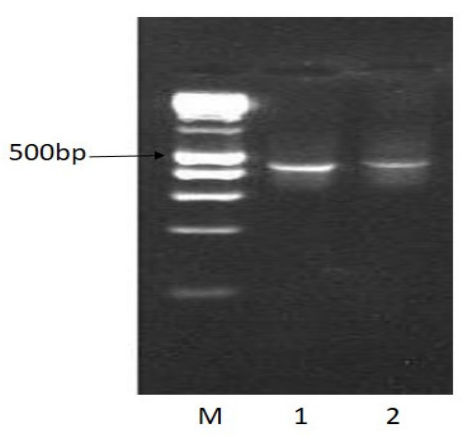

Figure 3: DNA bands of $S$. typhi isolates following agarose gel electrophoresis. (Key: $\mathrm{M}=\mathrm{DNA}$ Marker, 1 and $2=S$. typhi isolates) 


\section{Discussion}

Enteric fever is a persistent public health problem especially in economically developing countries characterized with lower level of hygiene and Page | 3636 poor sanitary conditions. In Nigeria specifically, enteric fever constitutes a great socio-medical problem being responsible for many cases of pyrexia of unknown origin (Akinyemi et al., 2008). Assessment of the possible influence of the mode of treatment on typhoid fever prevalence in the study sites reveals that the greater percentage participants reported to have used non-prescribed antibiotics. The persistent and unmonitored use of antibiotics has led to the emergence of resistant strains; it often results in a condition where the body becomes more vulnerable to diseases and then therapeutic efforts becomes difficult as the organism develops immunity against the antibiotic drugs in circulation (Wright, 2014). It was observed that over $40 \%$ of subjects in all study sites did not adhere to medication. Adherence is a primary determinant of the effectiveness of treatment because poor adherence lessens maximum clinical benefit (Dunbar-Jacob, 2000). Non-adherence could to lead to gene modification and replacement which consequently increases the resistance of organism to antibiotics. Over $70 \%$ of the subjects sourced their water from wells except in CSHG where $79 \%$ sourced their water from tap. Contamination of most well water could be due to the fact that most wells are dug close to septic tanks. This encourages the seepage of human waste which have been proven to be a transmission route of infectious agents into well water (EPA, 2017). Broken or improperly installed well covers could encourage pollution of the water source as this allows the entry of contaminant. From this survey, it is apparent that inadequate water supply is a serious socio-economic problem and has caused the subjects to resort to untreated well water for domestic water supplies. High risk of infection could be also traced to poor hygiene practices and sanitation conditions below standards and this was observed in the study sites.

The occurrence of typhoid fever among age brackets 0-20years being more susceptible is similar to the findings of Tran et al. (2005), that children and young adults were more susceptible than the elderly; however, an occurrence of typhoid fever in age group 51-60 years could be as a result of the immune system of the elderly waning over time. The susceptibility of children to typhoid fever is due to the fact that the immune system of children is not fully developed.

The multi-drug resistance observed in chloramphenicol, cotrimoaxazole and ampicillin is similar to the findings of Oyedum et al. (2016) who carried out a retrospective research on multidrug resistant $S$. typhi in Nigeria and reported high rate of resistance to chloramphenicol, cotrimoaxazole and ampicillin. The ethanol extract recorded better antibacterial activity as compared to the methanol extract which is in accordance with the findings of Geetha and Geetha (2014). This might be due to the extracting ability of the solvents. It therefore implies that ethanol may be a better extraction solvent for the leaf of this plant than methanol solvent. Most of the MIC values were lower than the MBC indicating that the extracts have bactericidal activity. Low MIC values are also an indication of high efficacy. All phytochemicals screened in this study were detected except alkaloids and saponins which were absent in the methanolic extract of the plant. This result is in accordance with the findings of Geetha and Geetha (2014).

The detection of these phytochemicals depends on the solvent used for extraction; as this study also suggests that ethanol is stronger solvent than methanol for the extraction of the phytochemicals of Cymbopogon citratus. The presence of phytochemicals in plant extracts can influence antimicrobial activities due to their important 
roles in bioactivity of medicinal plants (Oluduro and Omoboye, 2010). These classes of compounds (such as alkaloids, saponins flavonoids etc.) have been reported to have inhibitory activity against microorganisms and

Page | 3637 could therefore be a promising candidate for therapy. The confirmed isolates with polymerase chain reaction (PCR) at $500 \mathrm{bp}$ differs from report by Zhu et al. with a cloned primer that had 300bp. However, report by Haim et al., 2008 that detected rare Salmonella serovar Typhi strains possessing flagella antigens (fliC-j) was in in line with the result from this study and thus suggesting a rare strain of the bacteria from this location.

\section{Conclusions}

This study has been able to evaluate the incidence of antibiotic resistant $S$. typhi among out-patients in four (4) selected tertiary hospitals within Ilorin, Nigeria. The risk factors associated with enteric fever such as use of non-prescribed antibiotics, medication non-adherence, poor personal hygiene and consumption of contaminated water played a crucial role in the prevalence of typhoid fever among the subjects. Phytochemical assessment of the plants revealed the presence of seven (7) phytochemicals which might have contributed to the antibacterial activity of the plant extracts. The efficacy of Cymbopogon citratus leaves can serve as a promising candidate for therapeutic purposes.

\section{Conflict of Interest:}

The authors declare no conflicting interest in the publication.

\section{Acknowledgement}

The ministry of Health, Ilorin, Nigeria is appreciated for the approval in carrying out this research in Ilorin, Nigeria. The authors thank the Department of Plant Biology's Herbarium, University of Ilorin, Ilorin, Nigeria, for the Identification and authentication of the plant with voucher number UILH/001/1284.

\section{References}

Ahmad. I. and Beg, A. Z. (2001). Antimicrobial and phytochemical studies on 45 Indian medicinal plants against multi-drug resistant human pathogens. Journal of Ethnopharmacol. 74:113-23.

Akinyemi, K. O., Smith, S. I., Oyefolu, A. O. and Coker, A. O. (2008). Multidrug resistance in Salmonella enterica serovar typhi isolated from patients with typhoid fever complications in Lagos, Nigeria. Public Health, 119: 321-327.

Al-Mansoub, M., Asmawi, M. and Murugaiyah, V. (2013). Effect of extraction solvents and plant parts used on the antihyperlipidemic and antioxidant effects of Garcinia atroviridis: a comparative study. Journal of the Science of Food and Agriculture. 94(8):1552-1558.

Arya, V., Thakur, N. and Kashyap, C. (2014). Preliminary phytochemical analysis of the extracts of Psidium leaves. Middle East Journal of Scientific Research. 19(11): 17

Bauer, A.W., Kirby, W.M.M., Sherris, J.C., Turk, M. (1966). Antibiotic susceptibility testing by a standardized single disk method. American Journal Clinical Pathology. 45: 6493

Deng, W., Liou, S. R., Plunkett III, G., Mayhew, G. F., Rose, D. J., Burland, V. and Blattner, F. R. (2003). Comparative genomics of Salmonella enterica serovar typhi strains Ty2 and CT18. Journal of Bacteriology, 185: 2330-2337.

Dunbar-Jacob, J. (2000). Adherence in chronic disease. Annual Review of Nursing Research, 18:48-90.

Environmental Protection Agency EPA (2017). How Your Septic System Can Impact Nearby Water Sources. Available at: 
https://www.epa.gov/septic/how-yourseptic-system-can-impact-nearby-watersources

Ernst, E. (2008). Chiropractic: A critical Page | 3638 evaluation. Journal on Pain Symptom Management, 1-6.

Geetha, T.S. and Geetha, N. (2014). Phytochemical Screening, Quantitative Analysis of Primary and Secondary Metabolites of Cymbopogan citratus (DC) stapf. leaves from Kodaikanal hills, Tamilnadu. International Journal of PharmTech Research, 6: 521-529.

Haim, L., Souleymane, D., Sharon, M.T., Sofie, L., Samba, O.S., Milagritos, T., Patricia, I.F., Matthew, M., Boubou, T., Karen, L.K., Rosanna, L., James, P.N., James, E.G., Myron, M.L. (2008). PCR Method to Identify Salmonella enterica Serovars Typhi, Paratyphi A, and Paratyphi B among Salmonella Isolates from the Blood of Patients with Clinical Enteric Fever. 46 (5) 1861-1866; DOI: 10.1128/JCM.00109-08.

Joseph, M. (2005). Benefit of lemongrass oil. Edmon Agron Lemongrass as mosquito repellent. Word.

Kan, K. M. (1996). Serotype epidemiology and patterns of antibiotic susceptibility of Salmonella isolated in Hong Kong. China Medical Journal, 109(4):276-281.

Oluduro, A. and Omoboye, O. (2010). In Vitro Antibacterial Potentials and Synergistic Effect of South-Western Nigerian Plant Parts Used in Folklore Remedy for Salmonella typhi infection. Nature and Science 8(9): 525.9
Oyedum, U. M., Kuta, F.A. and Garba, S.A. (2016). A Retrospective Study of MultidrugResistant Salmonella typhiin Nigeria. UMYU Journal of Microbiology Research1: 80-82

Parkhill, J., Dougan, G., James, K. D., Thomson, N. R., Pickard, D., Wain, J. and Barrell, B. G. (2001). Complete genome sequence of a multiple drug resistant Salmonella enterica serovar typhi CT18. Nature, 413: 848-852.

Qamar, F. N., Azmatullah, A., Kazi, A. M., Khan, E. and Zaidi, A. K. M. (2014). A three-year review of antimicrobial resistance of Salmonella enterica serovars Typhi and Paratyphi $A$ in Pakistan. The Journal of Infection in Developing Countries, 8: 981986.

Sehra, D., Sehra, S., Ralia, P. and Sehra, S. T. (2013). An altered drug resistance pattern in Salmonella typhi. American Journal of Infectious Diseases and Microbiology, 1: 8485.

Sofowora, E. A., Olaniyi, A. A. and Oguntimehin, B. O. (1975). Phytochemical investigation of some Nigerian plants used against fevers. II. Cymbopogus citratus (Lemongrass). Plant Med. 28:186-187.

Wright, G. D. (2014). Something new: revisiting natural products in antibiotic drug discovery. Can. J. Microbiol.60(3):147-154.

Zaki, S. A. and Karande, S. (2011). Multidrugresistant typhoid fever: a review. The Journal of Infection in Developing Countries, 5: 324-337.

Zhu, Q, Lim, C.K., Chan, Y.N. (1996). Detection of Salmonella typhi by polymerase chain reaction. J Appl Bacteriol. 80(3):244-51. 